\title{
The Role Of Small Micro Enterprises In Production Snack And Product Innovation Towards Additional Community Economic Income In Tangerang City
}

\author{
Heri Satrianto ${ }^{1)}$ \\ heri.satrianto@ubd.ac.id \\ Berlin Silaban2) \\ berlin.silaban@ubd.ac.id \\ Rinintha Parameswari ${ }^{3}$ ) \\ rinintha.parameswari@ubd.ac.id \\ 1) 2) 3)Buddhi Dharma University Tangerang, Indonesia, Banten
}

\begin{abstract}
The study is intended to determine The Role of Small Micro Enterprises in Production Snack and Product Innovation towards an Additional Community Economic in Tangerang City.

Micro small and medium enterprises (MSMEs) have an important role in the economy of Indonesian society. Indonesia government also views the existence of MSME businessman as important. The existence of MSMEs can have an effect on increasing people's income and also with the innovation of snacks that can attract consumers.

The method used quantitative which was taken, it can be conclude that Whereas t count is 6,453> t table is 1,985 and the sig o.oo value $<0.05$, this shows that the role of Micro and Small Enterprises in production snacks has a significant and positive effect on the addition of community economic income in Tangerang City. That $t$ count is 5,568> t table is 1,985 and the sig 0.00 value $<0.05$, this shows that product innovation has a significant and positive effect on the addition of community economic income in Tangerang City. Whereas F count is 161,927> from F table of 3.09 and sig value of $0,000<0.05$, this shows that the Micro and Small Entrepreneurs Production snacks together with product innovation have a significant and positive effect on the addition of community economic income in Tangerang City.
\end{abstract}

Keyword: Small Micro Enterprises in Production Snack, Product Innovation, Economic Income 


\section{PRELIMINARY}

There are various factors that can affect a country's economy. In Indonesia, there is one area that also makes a major contribution to the economy. We know it as a micro business. As the name micro businesses are small businesses in Indonesia. Their fields are diverse, although small; they play a big role in the financial cycle of Indonesia.

Micro small and medium enterprises (MSMEs) have an important role in the economy of Indonesian society. Indonesia government also views the existence of MSME businessman as important. The proof, MSMEs together with cooperatives have a special place under the Ministry of Cooperatives and MSMEs the high attention given to MSMEs businessman is none other than a form of the government in supporting the economy of the small people. Moreover, MSMEs able to have a direct impact on people's lives in lower sectors. At least, there are 3 roles of MSMEs which are very important in the life of the small community. The three roles are:

1. Means to alleviate people from poverty.

2. Means for leveling the economy of the small people.

3. Provide foreign exchange income for the State.

Data from the Ministry of Cooperatives and MSMEs in 2017 shows the high foreign exchange of MSMEs businessman. The figure is very high, reaching 88.45 billion. With these three roles, it is not wrong if the MSMEs businessman cannot be underestimated. The snacks that are sold must be of good quality, both in terms of the ingredients used the processing and packaging aspects. The materials used must be hygienic and do not contain harmful substances. The processing method must be in accordance with the rules, for example, fry snacks with lowtemperature pressure frying technology, quality oil and replace it regularly. Then pack the fried snacks using good, attractive packaging and according to the brand packaging standards of these snacks.

\section{LITERATURE REVIEW}

\section{Micro Small Business}

The definition of MSMEs is a productive business owned by an individual or a business entity that has met the criteria as a micro business. As regulated in the law no. 20 of 2008, according to the definition of MSMEs, the criteria for MSMEs are differentiated respectively including micro, small and medium enterprises.

Micro enterprises are productive businesses owned by individuals and / or individual business entities that meet the criteria of micro enterprises as stipulated in Law Number 20 of 2008 concerning Micro, Small and Medium Enterprises (MSMEs). 
Small Business is a productive economic business that stands individually. Small Business as referred to in Law Number 20 Year 2008 concerning MSMEs. According to M. Kwartono, the definition of MSMEs is the economic activity of the people who have a maximum net worth of IDR 200,000,000 where land and buildings for business are not taken into account those who have an annual sales turnover of at most IDR. 1,000,000,000 and belong to Indonesian citizens. As explained in the definition of MSMEs as stated in the Presidential Decree No. 19 of 1998 as people's economic activities on a small scale that need to be protected and prevented from unfair competition. In the last decade, MSMEs businesses have started to appear, starting from a home scale to a larger scale. Culinary Business: One of the most popular MSMEs businesses among young people. With innovations in the field of food and capital that are not too big, this business is quite promising because every day everyone needs food, Fashion Business: Apart from food, MSMEs in the fashion sector are also in demand. Every year new fashion trends are always present which of course increases the income of fashion business people, Agribusiness Enterprises: agribusiness businesses in agriculture must capitalize on a large area of land. You can take advantage of the house yard which is transformed into a profitable agribusiness land.

\section{Snack Production}

The Snack Food Association (SFA) defines snacks as foods that have a small portion (relatively) and are generally rich in fat, rich in sugar, have water content from low to medium, and are commonly consumed between breakfast, lunch and dinner.

There are many snack food companies in Indonesia, which are best known to the public in general, including PT Indofood, Mayora, Nestle, Unilever, KraftFood, GarudaFood, Dua Kelinci, Siantar Top, Tiga Pilar Sejahtera, and so on. The products also vary; some are made from cassava, potatoes, beans, corn, tempe, starch, and so on.

\section{Product Innovation}

To get unique food ideas or innovations, of course, you have to frequently hunt for food. Traditional and international restaurants, so you can get creative business ideas and profitable food business ideas.

The main thing to think about is if you only prioritize the creative food business but don't pay attention to taste, then don't blame it if you won't be successful in running a profitable food business. Unique food innovations are no less interesting to try. Currently there is a food trend in the form of clothes, shoes, hats and others. One example is a tart in the form of shoes, clothes, sewing machines, make-up tools and others. There is even a face shaped like a birthday person. Indonesia is rich in traditional food; those who want to try a profitable food business can try 
foods that are not typical of the region so there is little competition. Especially if you open a Padang or Pempek restaurant, you will compete a lot. You can take an example of green banana ice, which at first people would not think that it is a typical Makassar culinary. Now successful in the market

\section{Community Economic Income}

According to Sukirno (2000) income is a very important element in a trading business, because in doing a business, of course you want to know the value or amount of income earned during doing the business. In an economic sense, income is remuneration for the use of production factors owned by the household sector and the corporate sector, which can be in the form of salaries / wages, rent, interest and profit (Hendrik, 2011). Income is a description of the economic position of the family in society, therefore everyone who is involved in a certain type of work, including work in the informal sector or trade, trying to increase the income from the results of his business which are used to meet the needs of his family. Operating Income is income arising from the sale of merchandise, products or services within a certain period in the framework of the main activity or which is the main objective of the company which is directly related to the main business (operation) of the company concerned. This income is normal in nature in accordance with the goals and business of the company and occurs repeatedly during the company's activities. The types of income can be distinguished as follows:

1. Income derived from the use of the company's assets or economic resources by other parties.

For example, income from interest, rent, royalties and others.

2. Income derived from the sale of assets other than merchandise or products. For example, sale of securities, sale of intangible assets.

Interest income, rent, royalties, profit (profit), sale of fixed assets, long-term investment and dividends are non-business income for companies engaged in manufacturing and trading. And income derived from an increase in equity from transactions that are not the primary activity of the entity and from transactions or other events and situations that affect identity other than those resulting from the owner's investment is called profit.

\section{Framework}

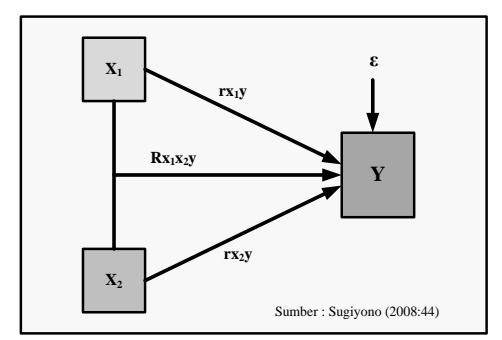




\section{Explanation:}

$\begin{array}{lll}\mathrm{X}_{1} & = & \text { Variable Role of Micro and Small Enterprises snack Production } \\ \mathrm{X}_{2} & = & \text { Product Innovation Variables } \\ \mathrm{Y} & = & \text { Variable of Community Economic Income Increase } \\ \varepsilon \text { (Epsilon) } & = & \text { Variables outside } \mathrm{X} 1 \text { and } \mathrm{X} 2 \text { that affect } \mathrm{Y} \text { will not be examined } \\ \mathrm{Rx}_{1} \mathrm{Y} & = & \text { Structural parameters of the effect of } \mathrm{X} 1 \text { on } \mathrm{Y} \\ \mathrm{Rx}_{2} \mathrm{Y} & = & \text { Structural parameters of the effect of } \mathrm{X} 2 \text { on } \mathrm{Y} \\ \mathrm{Rx}_{1} \mathrm{X}_{2} \mathrm{Y} & = & \text { The structural parameters influence } \mathrm{X} 1 \text { and } \mathrm{X} 2 \text { simultaneously on } \mathrm{Y}\end{array}$

\section{METHODOLOGY}

The type of data used is quantitative data, namely the type of data that can be measured (measurable) or calculated directly as a numeric or numeric variable. Variables in statistics are attributes, characteristics, or measurements that describe a case or object of research.

Sources of research data obtained directly from the original source in the form of interviews, polls from individuals or groups (people) as well as the results of observations of an object, event or test result (object). The sample size is determined using the Simple Random Sample Method, which is a sample consisting of $\mathrm{n}$ elements, which are selected from a population in such a way that each combination of $\mathrm{n}$ elements has the same chance of being selected as other combinations. The determination of the sample size uses the Slovin formula according to Sugiono (2017, p. 3), as follows:

Explanation:

$$
\begin{aligned}
\mathrm{n} & =\frac{N}{1+N(e)^{2}} \\
= & \frac{135}{1+135(0.05)^{2}} \\
& =100 \text { orang }
\end{aligned}
$$

$\mathrm{n} \quad: \quad$ Number of samples

$\mathrm{N} \quad$ : Total population

E : Erorr (\%which can be tolerated by the inaccuracy of using the sample as a substitute for the population)

\section{RESULTS AND DISCUSSION}

Reliability the Role of Micro and Small Enterprises in Production Snack Food

Scale: ALL VARIABLES

\section{Case Processing Summary}

\begin{tabular}{llr|r} 
& & \multicolumn{2}{c}{$\%$} \\
\hline \multirow{2}{*}{ Cases } & Valid & 99 & 99.0 \\
\cline { 2 - 4 } & Excluded $^{2}$ & 1 & 1.0 \\
\hline & Total & 100 & 100.0 \\
\hline
\end{tabular}

a. Listwise deletion based on all variables in the procedure. 
Reliability Statistics

Cronbach's Alpha $\mathrm{N}$ of Items

.876

10

It can be conclude that all the questionnaires regarding the variable of the role of micro and small enterprises in Production snacks are reliable.

\begin{tabular}{|c|c|c|c|c|}
\hline & & Item-Total Stat & istics & \\
\hline & $\begin{array}{l}\text { Scale Mean if } \\
\text { Item Deleted }\end{array}$ & $\begin{array}{c}\text { Scale Variance if } \\
\text { Item Deleted }\end{array}$ & $\begin{array}{l}\text { Corrected Item- } \\
\text { Total Correlation }\end{array}$ & $\begin{array}{c}\text { Cronbach's } \\
\text { Alpha if Item } \\
\text { Deleted }\end{array}$ \\
\hline $\mathrm{X} 1.1$ & 38.51 & 24.865 & .575 & .866 \\
\hline $\mathrm{X} 1.2$ & 38.62 & 24.851 & .592 & .865 \\
\hline $\mathrm{X} 1.3$ & 38.20 & 24.938 & .639 & .863 \\
\hline $\mathrm{X} 1.4$ & 38.28 & 23.858 & .647 & .861 \\
\hline $\mathrm{X} 1.5$ & 38.04 & 25.468 & .541 & .869 \\
\hline X1.6 & 38.93 & 24.352 & .508 & .873 \\
\hline $\mathrm{X} 1.7$ & 38.55 & 23.332 & .581 & .868 \\
\hline $\mathrm{X} 1.8$ & 38.35 & 23.374 & .688 & .857 \\
\hline $\mathrm{X} 1.9$ & 38.64 & 24.132 & .641 & .861 \\
\hline $\mathrm{X} 1.10$ & 38.07 & 24.760 & .645 & .862 \\
\hline
\end{tabular}

\section{Reliability Product Innovation}

Scale: ALL VARIABLES

\section{Case Processing Summary}

\begin{tabular}{llr|r} 
& \multicolumn{2}{c|}{$\mathrm{N}$} & \multicolumn{1}{c}{$\%$} \\
\hline \multirow{2}{*}{ Cases } & Valid & 100 & 100.0 \\
\cline { 2 - 4 } & Excluded $^{\mathrm{a}}$ & 0 & .0 \\
\cline { 2 - 4 } & Total & 100 & 100.0 \\
\hline
\end{tabular}

a. Listwise deletion based on all variables in the procedure.

From the case processing summary table above, it can be seen that the respondents studied in the questionnaire results regarding the Product Innovation variable were 100 respondents and none of the data were excluded from the analysis.

\section{Reliability Statistics}

\begin{tabular}{r|r} 
Cronbach's Alpha & N of Items \\
\hline .883 & 10 \\
\hline
\end{tabular}

In the reliability statistics table above, it can be seen that the Cronbach's Alpha value is 0.883 . It can be concluded the Product Innovation variable are reliable. 


\begin{tabular}{|c|c|c|c|c|}
\hline & $\begin{array}{l}\text { Scale Mean if } \\
\text { Item Deleted }\end{array}$ & $\begin{array}{c}\text { Scale Variance if } \\
\text { Item Deleted }\end{array}$ & $\begin{array}{l}\text { Corrected Item- } \\
\text { Total Correlation }\end{array}$ & $\begin{array}{c}\text { Cronbach's } \\
\text { Alpha if Item } \\
\text { Deleted }\end{array}$ \\
\hline X2.1 & 37.27 & 29.512 & .535 & .877 \\
\hline X2.2 & 37.17 & 29.415 & .598 & .873 \\
\hline X2.3 & 37.51 & 29.222 & .456 & .885 \\
\hline$\times 2.4$ & 37.55 & 27.866 & .735 & .862 \\
\hline X2.5 & 37.55 & 28.412 & .719 & .864 \\
\hline X2.6 & 37.46 & 28.150 & .716 & .864 \\
\hline X2.7 & 37.53 & 29.181 & .446 & .887 \\
\hline X2.8 & 37.41 & 28.931 & .672 & .868 \\
\hline X2.9 & 37.45 & 29.604 & .576 & .874 \\
\hline $\mathrm{X} 2.10$ & 37.41 & 27.658 & .783 & .859 \\
\hline
\end{tabular}

\section{From the table above it can be explained that:}

The authors made 10 statements about the addition of community economic income to find out whether all these statements were reliable or not.

\section{Scale: ALL VARIABLES}

\section{Case Processing Summary}

\begin{tabular}{llr|r} 
& \multicolumn{2}{c|}{$\mathrm{N}$} & \multicolumn{1}{c}{$\%$} \\
\hline \multirow{2}{*}{ Cases } & Valid & 99 & 99.0 \\
\cline { 2 - 4 } & Excluded $^{\mathrm{a}}$ & 1 & 1.0 \\
\cline { 2 - 4 } & Total & 100 & 100.0 \\
\hline
\end{tabular}

\section{a. Listwise deletion based on all variables in the} procedure.

From the case processing summary table above, it can be seen that the respondents studied in the questionnaire results regarding the training variable were 100 respondents and 1 data was excluded from the analysis.

\section{Reliability Statistics}

Cronbach's Alpha N of Items 
In the reliability statistics table above, it can be seen that the Cronbach's Alpha value is 0.909 . It can be concluded the data is reliable

\begin{tabular}{|c|c|c|c|c|}
\hline & & Item-Total Stat & tistics & \\
\hline & $\begin{array}{l}\text { Scale Mean if } \\
\text { Item Deleted }\end{array}$ & $\begin{array}{c}\text { Scale Variance if } \\
\text { Item Deleted }\end{array}$ & $\begin{array}{l}\text { Corrected Item- } \\
\text { Total Correlation }\end{array}$ & $\begin{array}{c}\text { Cronbach's } \\
\text { Alpha if Item } \\
\text { Deleted }\end{array}$ \\
\hline Y.1 & 38.04 & 28.774 & .670 & .900 \\
\hline Y.2 & 38.44 & 29.637 & .494 & .910 \\
\hline Y.3 & 38.15 & 26.926 & .768 & .894 \\
\hline Y.4 & 38.05 & 28.395 & .695 & .899 \\
\hline Y.5 & 38.02 & 28.551 & .712 & .898 \\
\hline Y.6 & 38.03 & 28.948 & .658 & .901 \\
\hline Y.7 & 38.09 & 27.961 & .693 & .899 \\
\hline Y.8 & 38.06 & 27.976 & .809 & .893 \\
\hline Y.9 & 38.42 & 27.247 & .594 & .908 \\
\hline Y.10 & 37.96 & 28.019 & .698 & .898 \\
\hline
\end{tabular}

\section{From the table above it can be explained that:}

If we compare the rtabel with the rtabel value in the Corrected Item-Total Correlation column, the $r$ count value of all statements regarding the increase in brand community economic income is greater than the $r$ table, meaning that all statements are valid.

\section{Multiple Assumption and Regression Test Analysis}

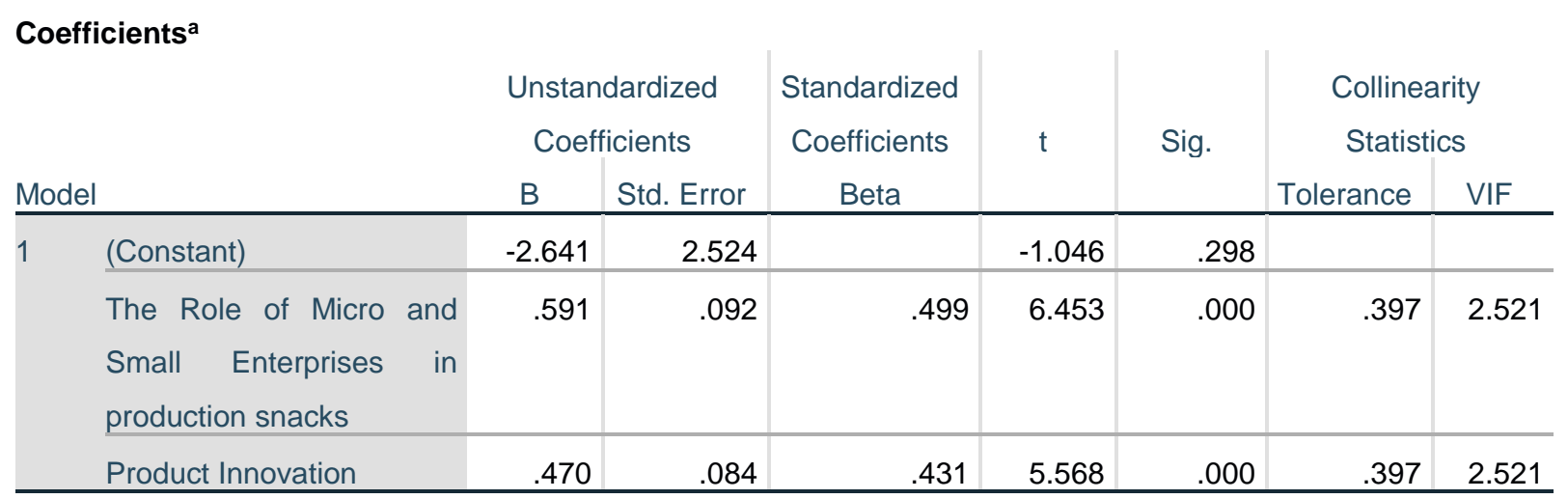

a. Dependent Variable: Penambahan Penadapatan Ekonomi Masyarakat

From the output above, the VIF (Variance Inflation Factor) value of each independent variable for the price variable is 1.159 , for the location variable is 1.753 , for the promotion variable is 1.261 and for the service variable is 1.818 in this model it is below 10 and the Collinearity tolerance value For a price of .863 , the Collinearity tolerance value for the location is .571 , the 
Collinearity tolerance value for promotion is .793 and the Collinearity tolerance value for services is .550 in this model is above 0.10 so that the regression model is free from multicollinearity problems.

\section{Multiple Regression Analysis:}

\section{Descriptive Statistics}

\begin{tabular}{l|r|r|r} 
& Mean & Std. Deviation & \multicolumn{1}{c}{ N } \\
\hline $\begin{array}{l}\text { Additional Community } \\
\text { Economic Income }\end{array}$ & 42.09 & 6.454 & 100 \\
$\begin{array}{l}\text { The Role of Micro and Small } \\
\begin{array}{l}\text { Enterprises Production Snack } \\
\text { food }\end{array}\end{array}$ & 42.63 & 5.453 & 100 \\
\hline \begin{tabular}{l} 
Product Innovation \\
\hline
\end{tabular} & 41.59 & & \\
\hline
\end{tabular}

The average increase in community economic income with a total of 100 data is 42.09 with a standard deviation of 6,454 the average role of small and micro enterprises in Production snacks with a total of 100 data is 42.63 with a standard deviation of 5,453 . The average product innovation with a total of 100 data is 41.59 with a standard deviation of 5,924

\section{Correlations}

\begin{tabular}{|c|c|c|c|c|}
\hline & & $\begin{array}{l}\text { Additional } \\
\text { Community } \\
\text { Economic Income }\end{array}$ & $\begin{array}{l}\text { The Role of Micro } \\
\text { and Small } \\
\text { Enterprises in } \\
\text { Production Snacks }\end{array}$ & Product Innovation \\
\hline \multirow[t]{4}{*}{ Pearson Correlation } & Additional Community & 1.000 & .834 & .819 \\
\hline & Economic Income & & & \\
\hline & $\begin{array}{l}\text { The Role of Micro and Small } \\
\text { Enterprises in Production } \\
\text { Snacks }\end{array}$ & .834 & 1.000 & .777 \\
\hline & Product Innovation & .819 & .777 & 1.000 \\
\hline \multirow[t]{4}{*}{ Sig. (1-tailed) } & Additional Community & . & .000 & .000 \\
\hline & Economic Income & & & \\
\hline & $\begin{array}{l}\text { The Role of Micro and Small } \\
\text { Enterprises in Production } \\
\text { Snacks }\end{array}$ & .000 & & .000 \\
\hline & Product Innovation & .000 & .000 & \\
\hline \multirow[t]{2}{*}{ N } & $\begin{array}{l}\text { Additional Community } \\
\text { Economic Income }\end{array}$ & 100 & 100 & 100 \\
\hline & $\begin{array}{l}\text { The Role of Micro and Small } \\
\text { Enterprises in Production } \\
\text { Snacks }\end{array}$ & 100 & 100 & 100 \\
\hline
\end{tabular}


The magnitude of the relationship between the increase in community economic income with the role of micro and small enterprises in production snack food which is calculated with a correlation coefficient of 0.834 , the relationship between the increase in community economic income and product innovation calculated with a correlation coefficient of 0.819 .

The significance level of the correlation coefficient of output is measured by the probability level of producing a number of 0.000 , because the significant level of probability is 0.000 below 0.05 , so the correlation between the role of micro and small enterprises in making snack snacks and product innovation is very real.

\section{Variables Entered/Removed ${ }^{\mathrm{a}}$}

\begin{tabular}{ll|l|l} 
Model & \multicolumn{1}{c}{ Variables Entered } & Variables Removed & Method \\
\hline 1 & $\begin{array}{l}\text { Product Innovation, the Role of Micro, Small Businesses in } \\
\text { Production Snacks }\end{array}$ & . Enter \\
\hline
\end{tabular}

a. Dependent Variable: Additional Community Economic Income

b. All requested variables entered.

\begin{tabular}{lr|r|r|r|}
\multicolumn{9}{c}{$\begin{array}{l}\text { Model Summary } \\
\text { Model }\end{array}$} & R & & \multicolumn{2}{c|}{$\begin{array}{c}\text { Std. Error of the } \\
\text { Estimate }\end{array}$} \\
\hline 1 & $.877^{\mathrm{a}}$ & .770 & .765 & 3.130 \\
\hline
\end{tabular}

a. Predictors: (Constant), Product Innovation, the Role of Micro and Small Businesses in Snack Production.

b. Dependent Variable: Additional Community Economic Income

$\mathrm{R}=0.877$ means that the correlation coefficient is 0.877 . This figure shows the degree of correlation (relationship) between the Product Innovation variable, the Role of Micro and Small Businesses of Production Snack Food, to the Increase in Community Economic Income

\begin{tabular}{|c|c|c|c|c|c|c|}
\hline \multicolumn{7}{|c|}{ ANOVA $^{a}$} \\
\hline \multicolumn{2}{|c|}{ Model } & Sum of Squares & $\mathrm{df}$ & Mean Square & $\mathrm{F}$ & Sig. \\
\hline \multirow[t]{3}{*}{1} & Regression & 3173.633 & 2 & 1586.817 & 161.927 & $.000^{\mathrm{b}}$ \\
\hline & Residual & 950.557 & 97 & 9.800 & & \\
\hline & Total & 4124.190 & 99 & & & \\
\hline
\end{tabular}

a. Dependent Variable: Additional Community Economic Income

b. Predictors: (Constant), Product Innovation, the Role of Micro and Small Businesses in Snack Production 


\section{Hypothesis Testing Test $\mathbf{F}$}

The results of this test determined that the calculated $\mathrm{F}$ value of 161,927 is greater than the $\mathrm{F}$ table of $3.09(0,000$ because of the sig value. $\alpha<0.05$ Ho is rejected Ha accepted means that the dependent variable is the role of Micro, Small Businesses in Production Snack Food and Product Innovation simultaneously / together having a significant effect on independent variable.

\begin{tabular}{|c|c|c|c|c|c|c|c|c|}
\hline \multicolumn{9}{|c|}{ Coefficients $^{\mathrm{a}}$} \\
\hline & & $\begin{array}{r}\text { Unstanc } \\
\text { Coeffi }\end{array}$ & $\begin{array}{l}\text { ardized } \\
\text { iients }\end{array}$ & $\begin{array}{l}\text { Standardized } \\
\text { Coefficients }\end{array}$ & $\mathrm{t}$ & Sig. & $\begin{array}{c}\text { Collinearity } \\
\text { Statistics }\end{array}$ & \\
\hline \multicolumn{2}{|c|}{ Model } & $\mathrm{B}$ & Std. Error & Beta & & & Tolerance & VIF \\
\hline \multirow[t]{4}{*}{1} & (Constant) & -2.641 & 2.524 & & -1.046 & .298 & & \\
\hline & The Role of Micro and & & .092 & .499 & 6.453 & .000 & .397 & 2.52 \\
\hline & $\begin{array}{l}\text { Small Enterprises in } \\
\text { making snacks }\end{array}$ & & & & & & & 1 \\
\hline & Product Innovation & .470 & .084 & .431 & 5.568 & .000 & .397 & 2.52 \\
\hline
\end{tabular}

a. Dependent Variable: Additional Community Economic Income

\section{Conclusion}

.1. Whereas $t$ count is $6,453>t$ table is 1,985 and the sig 0.00 value $<0.05$, this shows that the role of Micro and Small Enterprises in Production snacks has a significant and positive effect on the addition of community economic income in Tangerang City.

2. That $\mathrm{t}$ count is $5,568>\mathrm{t}$ table is 1,985 and the sig 0.00 value $<0.05$, this shows that product innovation has a significant and positive effect on the addition of community economic income in Tangerang City.

3. Whereas F count is $161,927>$ from $F$ table of 3.09 and sig value of $0,000<0.05$, this shows that small micro entrepreneurs production snack food together with product innovation have a significant and positive effect on the addition of community economic income in Tangerang City. 


\section{REFERENCES}

Atsarina Luthfiyyah, 2019 Resep Keripik Singkong, Bidang Tataboga, Ilmu Komunikasi Universitas Gadjah Mada

Asosiasi Penyelenggara Jasa Internet Indonesia [APJII]. (2018). Profil Pengguna Internet Indonesia. Jakarta: Asosiasi Penyelenggara Jasa Internet Indonesia.

Badan Pusat Statistik Jakarta Pusat , 2017. Statistik Indonesia Tahun 2017. Jakarta Pusat: Badan Pusat Statistik.

Craven, D.W. \& Piercy, N.F. (2012). Strategic Marketing. Teenth Edition. New York: McGrawHill/Irwin.

Endang Harningsih dan Rintar Agus Harilintar, Faktor - faktor Yang Mempengaruhi Kinerja Usaha Pedagang Eceran Jurnal: jpmanajemen dd080093

Harhayadi, 2011, Citarasa makanan ringan. berbeda-beda, ada yang manis, asin, gurih, dan bahkan pedas. Snack Food.

Heidrick and Struggles. (2009). The Adoption of Digital Marketing in Financial. Services Under Crisis.

Ina Primiana, Prof. Dr., S.e., M.t.,2003 - 2009, Menggerakan Sektor Riil UMKM \& Industri dalam Sektor Ekonomi, Alfabeta

Kanaidi, SE, M.Si, 2010,Koperasi dan UMKM, (Koperasi Usaha Mikro Kecil dan Menengah), Manajemen Bisnis Politeknik Pos Indonesia, Bandung.

Kotler, Philip and Gerry Armstrong, 2012. Prinsip-Prinsip Pemasaran. Edisi 13 Jilid 1. Jakarta: Erlangga

Marrus, Stephanie K. 2001. Strategic Management In Action. PT. Gramedia Pustaka Utama, Jakarta

M. Kwartono, 2009, Kiat Sukses Berburu Modal UMKM, Raih Asa Sukses, Jakarta

Munandar, 2006, Teori Pendapatan Ekonomi,

Nuran Wibisono, 2016, Olahan Daging dalam Jagat Kuliner Dunia, Gaya Hidup tirto.id

Rudjito. 2003. Strategi Pengembangan Umkm Berbasis Strategi Bisnis, Makalah Study Kasus Bank BRI

Sanjaya, Ridwan dan Josua Tarigan.(2009).Creative Digital Marketing. Jakarta: PT Elex Media Komputindo 